\title{
Mobile Learning in Malaysian Universities: Are Students Ready?
}

\author{
http://dx.doi.org/10.3991/ijim.v10i3.5316 \\ Issham Ismail, Siti Norbaya Azizan, Thenmolli Gunasegaran \\ Universiti Sains Malaysia, Penang, Malaysia
}

\begin{abstract}
Prior to embarking on mobile learning, it is critical for learning institutions to research the area of finding the right ingredient for the right learners by firstly seeking whether they are ready to adapt to the mobility of learning. Adding a Malaysian perspective, the purpose of this paper was to present a quantitative study on university students' readiness for the integration of mobile technologies in education system within their learning institutions. The study was carried out in 11 public universities in Malaysia, whereby 55 questionnaires were randomly distributed to students in each campus. Out of a total of 605 questionnaires distributed, 551 were returned. Overall, the descriptive results were relatively neutral and thus, indicating that they were moderately ready for the educational use of mobile technology. Furthermore, some were quite concerned on cost issue. Despite this, respondents were somewhat agree that they are interested to know more about mobile learning. As a result of the data analysis, some important issues emerged which give rise to the importance of assessing students' readiness for a successful implementation of mobile learning. These findings may function as anchor-points for further research should mobile learning is to be employed widely in Malaysian higher education setting.
\end{abstract}

Index Terms-awareness, higher education, Malaysia, mobile learning, readiness.

\section{INTRODUCTION}

The twentieth century witnessed a drastic penetration of technology in education system throughout the world. Technologies are always seemed by most education providers as catalysts which can revamp the process of teaching and learning. With the aid of technology, instructors will be able to conduct teaching to the extent that is beyond the traditional classroom setting. Concurrently, learners will be able to experience learning in ways that have not been possible before: active learning [1], and positively motivated on the learning processes [2]. As a result from these learning outcomes, many initiatives have been spearheaded for educational advantages, including the incorporation of computer assisted, computer mediated methodologies [3] and in recent years, the mobile technology.

Mobile technology is one of the technology advances that are considered to be one of a new paradigm of higher education nowadays. This utilization of mobile devices in education is mostly referred as mobile learning [4]. Mobile learning emerged in response to the need of ubiquitous and 'on-the-go' access to learning which completes the missing puzzle in face-to-face classroom. With the use of mobile devices such as mobile phone, smart phone, and Personal Digital Assistants (PDA), mobile learning is gaining popularity in its ability to facilitate teaching and learning activities, such as monitoring students' performance [5] and disseminating learning contents [6]. One of the push effects that make this technology a potential for teaching-learning purposes is the increasing usage of mobile devices among the younger generation. For instance, in Malaysia, it was reported by the Malaysian Communication and Multimedia Commission [7] that the penetration rate of mobile in Malaysia for the year 2010 is $106 \%$, which implies multiple subscriptions among users. Moreover, it was also reported that the youth mobile subscribers account for more than $30 \%$ of total mobile subscribers in Malaysia [8]. In line with this potential of mobile devices in education, much research has been carried out to evaluate the effectiveness of mobile technology integration with pedagogy. For instance, several scholarly research has reported that mobile learning helps to improve communication and enrich students' learning experiences [9], provides better learning access for distance learners [10] and impacts learners motivation, collaboration, information sharing, mobility and interactivity [11]. Despite the benefits, a successful mobile learning implementation however, does not come without challenges.

As other educational technologies, the success or failure of mobile learning implementation will also depend on human factors. Among of the human factors that need to be urgently addressed before a successful implementation of mobile learning is the learners' readiness in embracing the technology for their learning. Several studies have reported their findings on respondents' readiness for mobile learning in terms of their ownership of mobile devices [12][13][14]. However, even if a student uses a mobile device frequently, it does not mean that he would be ready to use it for learning [12]. Another readiness issue to ponder is whether or not the students aware of the benefits mobile learning could bring to them in the first place. As been found in another study [15], the students are not fully aware of the value of mobile learning to them. If students do not see the benefits, making them ready for the educational technology might still hard to achieve. Nonetheless, there is still little research that explores the aforementioned issue.

Thus, this study will add to the literature on a nationwide research and exploration related to students' readiness for mobile learning from the perspective of Malaysian higher education. Are students in Malaysian universities ready for mobile learning and technology in education? What are influencing factors of their readiness for mobile learning?This paper sought to investigate these issues and thus, present the significant implications of the study findings for future research. 


\section{LITERATURE REVIEW}

\section{A. Technology in Education}

In education nowadays, the use of technology is almost essential as a supplement to the face-to-face classroom approach. The emergence of innovative technologies has inspired many educational practitioners to incorporate technology into education to cater the learning needs of 21 st century learners. The technologically sophisticated learners for whom technology access and ownership has become an inseparable element and is a way of life [16], now entering the age of higher education [17] has promoted changes in pedagogy, remodel the curricula and teaching methodologies [18]. The digital generations who are also known as digital natives, introduced by Mark Prensky [19], Millennial Generation, Internet Generation, Digital Natives, Echo Boomers, Boomlets, Nesters, Generation Y and Nintendo Generation refers to individuals born after 1980 [20][21][17] and raised during the dot.com boom, and have seen the development of MP3 players, YouTube, and smartphones has the ability to multitask and utilizing technological devices simultaneously [22]. The unique trait of these millennial learners does not only shaped the personalities but also contributes towards their learning preferences that has created a need for new tools and supplemental learning environments such as multiple media and simulation based environments [17], interactive learning environments [23], less lecture, active learning approaches, multimedia enriched environment, collaborating with peers [24][25] are some of the pedagogical approaches to reach the digital generation.

The existing literature on the impact of technology on education is many. Educational technology has significant implication in promoting learning, improves the quality of education by facilitating self-learning, collaborative learning, problem solving aptitude, critical thinking, ability to communicate and space for real time conversation [26], at the same time making the traditional method more meaningful and affective [27]. In this sense, conventional teaching approaches alone may not address the learning preferences of the Millennials, teaching methodology has to be aligned with the way Millennials learn, to achieve the optimal learning experience. With a greater need for technology in education, researches are needed to get the mix right.

\section{B. M-Learning: Mobility for Learners}

The evolution of portable handheld devices and wireless technology has transformed many aspects of people's daily life around the globe [28]. Ownership of mobile devices has reached critical mass around the world [29] and it is also predicted that by 2016,25 percent of all mobile phone owners around the world will have more than one mobile device [30]. The fact is, these technological devices have become a must-have gadget due to its mobility features. These devices include mobile phones, laptops and media devices that are easy to carry around and keep us connected with variety of information at all time. Abundance of these mobile technologies has also added value into educational atmosphere thereby opens door for practitioner, educators and education policy makers to consider the implications of these devices for modern teaching and learning environment [28][31]. Recent advancement in the wireless mobile technologies has facilitated this new method of learning as mobile learning
[32]. Mobile learning is not merely the combination of 'mobile' and 'learning'[33][34]. Mobile learning or mlearning is a rising art of using mobile or wireless devices to enhance the learning experience while on the move [35][31]. According to Kukulska-Hulme and Traxler [36], devices used for mobile learning includes cell phones, smartphones, palmtops, handheld computers, tablet PCs, laptops, and personal media players. To date, there has never been a specific definition of 'mobile learning' [33]. However, based on the literatures, m-learning is defined as "e-learning through mobile computational devices: Palms, Windows CE machines, even your digital cell phone" [37]; complement e-learning by creating an additional channel of access for users of mobile devices such as hand phones, PDAs, MP3 and MP4 players [38]; leverages learning on the mobile device's portability and affordability [39]; acquisition of any knowledge and skill through the use of handheld technology, anywhere and anytime [40] and "exploitation of ubiquitous handheld hardware, wireless networking and mobile telephony to enhance and extend the reach of teaching and learning"[41]. Others viewed mobile learning as "mediated learning through mobile technology" [42]; useful component of the flexible learning model in making the educational process "just in time, just enough and just for me" [43]; "an extension of e-learning" [44] and "transformative innovations for learning futures" [45].

Even though reviews indicate that mobile learning has close relationship with e-learning and d-learning (distance learning), mobile learning is actually distinct from elearning and d-learning [33]. Many researchers acknowledged that m-learning is entirely different from e-learning for its unique characteristics, such as spontaneous, private, portable, situated, informal, bite-sized, light-weight, context aware, connected, personalized, interactive, and mobile [40][46][47][48][49]. The dynamic context of mobile technologies can relate to six types of learning or 'categories of activity', namely behaviorist, constructivist, situated, collaborative, informal/lifelong, and support/coordination [47]. Realizing the potential of mobile technologies to support learning, more and more institutions around the world is now adopting this new mode of learning, due to its significant benefits that include cost effectiveness, convenience, motivation to learn, accessibility; anytime and where, flexibility, as well as immediacy of information and interaction [50][51][52][53]. Mobile learning undoubtedly has potential to transform learning from conventional 'chalk and talk' mode towards more digitally-rich, 21 st century learning environment that suits the characteristic of millennial learners, who accustomed having all knowledge at their fingertips. It is clear that those millennial learners would benefit significantly from mobile learning abound, as they have developed an information technology mindset and multitasking skills [54] where they learn best when the learning happens in a socially constructed and contextual, self-controlled method [54][55]. So, through mobile learning it is expected that this mode would suit the learning style and preferences of today's learners and engage students for a better education performance and outcomes [56]. Even though mobile learning's visibility and significance is growing, it is evidently undeveloped as compared to other technologies and their pedagogies [34]. 


\section{M-Learning in Malaysia}

In Malaysia, as reported by the Malaysian Communication and Multimedia Commission, mobile phones penetration in the last four years kept growing tremendously in most states and main mobile phone users were found to be those ranging from 20 to 49 years in age. [57]. Regardless of the growing popularity, mobile learning in Malaysia is still in its infancy [58][59][60]. According to Pollara, most of the studies are still focusing on the idea of establishing foundation, theory, design, type of m-learning and activities supported by mobile technologies [61]. While a plethora of studies that explore the potential of m-learning for learning and the ownership of the mobile phones, the major focus of m-learning lays on the learning itself rather than the technology represented by the mobile phones [62]. Despite this, much less evidence exists as to how mobiles promote new learning [62]. The ownership and use of mobile devices alone does not merely guarantee that mobile learning will take place [63], in order to reach the level of adaption the learners must have adequate knowledge and awareness to use a technology in their educational environment [64]. If the goal is to achieve an intended learning outcome, it is of primary importance to investigate how ready the learners in terms of attitude and acceptance in embracing mobile learning [32]. Readiness for change which involves acceptance is an essential aspect to investigate whether changes are supported when implementing new learning innovation [32]. The technology readiness index by Parasuraman and Colby in 2001 measures the readiness while technology acceptance model by Davis in 1989 is used when implementing mobile learning to learners. It is clear that some of the concerns addressed above seem to be an important first step in increasing students' awareness and readiness to embrace mobile learning.

\section{Methodology}

The undertaken study was descriptive in nature. It deployed a quantitative survey method to investigate the level of mobile learning readiness among students in 11 public universities in Malaysia. The questionnaires were distributed randomly to 55 students from each university by means of directly approaching those who were passing at selected areas, such as library, cafeteria, and hostel. Before each survey was carried out, respondents were given a briefing on the purpose of the survey being conducted. A total of 551 responses were received from a total of 605 questionnaires being distributed to all the universities, providing a $91.07 \%$ response rate. The face and content validity of the questionnaire instrument were evaluated by experts in the faculty and related field. The questionnaire was pilot tested to undergraduate students in Universiti Sains Malaysia.

The questionnaire consisted of 3 sections: demographic information, readiness for mobile learning, and technology readiness. The first section consisted 7 demographic questions, which are gender, age, ethnic group, program of study, year of study, current institution, and field of study. The second section contained 10 items surveying students' readiness for mobile learning which adapted the MLR instrument developed by Hussin et al. [62]. As for the third section, it contained 22 items on technology readiness adapted from the Technology Readiness Index (TRI) as developed by Parasuraman [65]. All items were close-ended type. Sections on readiness utilized five-point
Likert scale ranging from "Strongly Disagree" (1) to "Strongly Agree" (5).

Data collected were pooled and analyzed by using the Statistical Package for Social Science (SPSS) version 20. Statistical analyses used for the data analysis were descriptive analysis and correlation analysis. Unless stated, all statistical analyses reported were conducted with a significant level of 0.05 .

\section{DATA ANALYSIS AND FINDINGS}

\section{A. Demographic Profiles}

Respondents' demographic profiles were summarized in Table 1. As can be seen, most respondents' age were between 20 to 30 years old $(75.3 \%)$ whereby majority of total respondents were female $(62.4 \%)$. In terms of ethnicity, $78.0 \%$ of respondents were Malay, followed by Chinese $(10.7 \%)$, other ethnics $(8.3 \%)$, and Indian $(2.9 \%)$. As for study background, it appears that most respondents were undertaking degree program $(77.1 \%)$ at the time the study was conducted in which some in their first year $(32.5 \%)$, second year $(30.9 \%)$, third year $(29.4 \%)$, and the remaining $(7.2 \%)$ in their fourth year. A majority group of them were from Sciences study field (37.9\%), followed by Management (21.6\%), Social Science (20.0\%), Art (16.7\%), and Engineering (3.8\%).

TABLE I.

DEMOGRAPHIC PROFILES

\begin{tabular}{|c|c|}
\hline Variables & $n(\%)$ \\
\hline \multicolumn{2}{|l|}{ Age (years) } \\
\hline Below 20 & $127(23.0)$ \\
\hline $20-30$ & $415(75.3)$ \\
\hline $31-40$ & $8(1.5)$ \\
\hline $41-50$ & $1(0.2)$ \\
\hline \multicolumn{2}{|l|}{ Gender } \\
\hline Male & 207 (37.6) \\
\hline Female & $344(62.4)$ \\
\hline \multicolumn{2}{|l|}{ Ethnicity } \\
\hline Malay & $430(78.0)$ \\
\hline Chinese & $59(10.7)$ \\
\hline Indian & $16(2.9)$ \\
\hline Others & $46(8.3)$ \\
\hline \multicolumn{2}{|l|}{ Program } \\
\hline Professional & $6(1.1)$ \\
\hline $\mathrm{PhD}$ & $12(2.2)$ \\
\hline Master & $21(3.8)$ \\
\hline Degree & $425(77.1)$ \\
\hline Diploma & $8(1.5)$ \\
\hline Certificate & $76(13.8)$ \\
\hline Others & $3(0.5)$ \\
\hline \multicolumn{2}{|l|}{ Year } \\
\hline Year 1 & $177(32.5)$ \\
\hline Year 2 & 168 (30.9) \\
\hline Year 3 & $160(29.4)$ \\
\hline Year 4 & $39(7.2)$ \\
\hline \multicolumn{2}{|l|}{ Study field } \\
\hline Sciences & 209 (37.9) \\
\hline Social sciences & $110(20.0)$ \\
\hline Art & $92(16.7)$ \\
\hline Management & 119 (21.6) \\
\hline Engineering & $21(3.8)$ \\
\hline
\end{tabular}


PAPER

MobiLE LEARNING IN MALAYSIAN UNIVERSITIES: ARE STUDENTS READY?

\section{B. Reliability Analysis}

Table II shows the results of reliability analysis for two variables, which are mobile learning readiness and technology readiness. As can be observed, the cronbach's alpha coefficients for both variables exceeded minimum value for exploratory study, which is 0.60 [66]. Therefore, both variables in this study were deemed to be reliable.

TABLE II.

CRONBACH'S ALPHA COEFFICIENTS

\begin{tabular}{lc}
\hline \multicolumn{1}{c}{ Variables } & Cronbach's Alpha \\
\hline Mobile learning readiness & 0.688 \\
Technology readiness & 0.774 \\
\hline
\end{tabular}

\section{Students' Readiness for Mobile Learning}

Descriptive analysis was done to study respondents' readiness for the use of mobile learning in their learning institution. Results of the analysis were summarized in Table III

As can be seen, in terms of mobile learning readiness, respondents mostly agreed that they want to know more about mobile learning (mean=3.83). This finding indicated respondents' interest to learn more about mobile learning as they did not quite sure what mobile learning is all about $($ mean=2.92). However, in general, respondents were moderately ready for mobile learning if it is to be implemented by their university (mean=3.05). They did not quite sure that they would prefer the lecturer to integrate mobile learning in their course (mean=2.92). In addition, there also seemed to be a concern among some respondents pertaining to the cost issue whereby they afraid that they would spend more money if mobile learning is implemented (mean=3.56). Furthermore, not many agreed that they do not mind paying extra money for mobile learning (mean=2.74). Due to this, some of them seemed to prefer conventional learning than mobile learning (mean=3.52) and some even not quite sure whether mobile learning is good for them (mean=3.21).

Overall, an overall mean value of 2.989 which is considered to be close to the neutral position suggested that respondents were generally undecided in their perceived readiness for mobile learning. Therefore,respondents can be said to be moderately ready for the use of mobile learning as a learning tool in their university.

\section{Students' Readiness for Technology}

Descriptive analysis was also conducted to study respondents' readiness for technology in general. Results of the analysis were shown in Table IV.

As can be observed, most respondents somewhat agreed that products and services that use the technologies are much more convenient to use (mean=3.85) and they are always open to learning about new and different technologies (mean=3.76). Respondents also somehow agreed that technology gives them more control over their daily lives (mean=3.65). Therefore, respondents were quite optimistic and innovative about technology in general. Despite this, some respondents also quite agreed that society should not depend heavily on technology to solve its problems (mean=3.67).

Nevertheless, with an overall mean of 3.299 which is slightly above the neutral point, respondents were found to be generally neutral in terms of their technology readiness. In similar vein, respondents can be said to be moderately ready in terms of technology in general.

\section{E. Factors Infuencing Students' Readiness for Mobile Learning}

In order to identify factors that could influence respondents' readiness for mobile learning, Pearson correlation analyses were used to study whether there is a relationship between respondents' mobile learning readiness and their demographic factors as well as their technology readiness. Correlation results were summarized in Table V.

As can be seen, the correlation analysis has confirmed the significant positive relationship between mobile learning readiness and technology readiness (at 0.01 confidence level). Therefore, it is safe to infer that respondents' readiness for mobile learning is influenced by their readiness for technology in general. On the other hand, the analyses also indicated that there were no significant relationships between respondents' mobile learning readiness and their demographic factors. Thus, demographic factors did not seem to have influences on respondents' readiness for mobile learning.

\section{DISCUSSIONS AND CONCLUSION}

Findings of this exploratory study underlined important insights pertaining to university students' readiness for the educational use of mobile technologies from the Malaysian perspective. It was revealed in this study that, an overwhelming majority of students in Malaysian public universities were still moderately ready for mobile learning. Many of them seemed to be not quite familiar with such learning approach even though there is an interest among them to learn more about mobile learning. Furthermore, there was also moderate level of awareness among respondents on the educational benefits of mobile technologies. This could imply that they did not really understand the benefit that they could gain through mobile learning. Furthermore, cost issue is considerably a concern among respondents if mobile learning is implemented at their university.

It can be inferred that, even though mobile technology is a growing popularity in this country [57], mobile learning is in fact still in its infancy in Malaysia [67][68] [35]. The implementation of mobile learning in Malaysian higher education is still not widespread due to several factors, such as cost issue, pedagogical and technological challenges [67] as well as policy constraint [69]. Since mobile learning is still at its early stage in this country, students are not certain as to how to best engage in this learning approach [62]. Moreover, university students generally use mobile technology for communication purpose, rather than for learning [70]. This finding also concurs with another study which investigated about students' perception on mobile learning whereby it was found that students seemed to be undecided about the use of mobile learning in education even though they have positive opinions about mobile learning [71].

In terms of influencing factors that determine Malaysian university students' readiness for mobile learning, our study found that students' readiness for technology in general could be one of the factors. On the other hand, demographic factors did not seem to have influences on respondents' readiness for mobile learning. It was found 
PAPER

Mobile LeARning In Malaysian Universities: ARE StUdents ReAdy?

TABLE III.

DESCRIPTIVE STATISTICS OF RESPONDENTS’ MOBILE LEARNING READINESS

\begin{tabular}{|c|c|c|c|}
\hline & $\begin{array}{c}\text { Items } \\
(\text { Overall } \text { mean }=2.989)\end{array}$ & Mean & $\begin{array}{l}\text { Standard } \\
\text { Deviation }\end{array}$ \\
\hline 1 & I know what mobile learning is all about. & 2.92 & 1.078 \\
\hline 2 & I want to know more about mobile learning. & 3.83 & 0.923 \\
\hline 3 & I prefer conventional learning than mobile learning. & 3.52 & 0.941 \\
\hline 4 & I think mobile learning is good for me. & 3.21 & 0.910 \\
\hline 5 & I don't mind paying extra money for mobile learning. & 2.74 & 0.988 \\
\hline 6 & Mobile learning will make my life difficult. & 2.85 & 0.941 \\
\hline 7 & I am not ready for mobile learning if the university implements it now. & 3.05 & 1.027 \\
\hline 8 & I would like my lecturer to integrate mobile learning in my class in addition to face-to face meeting in the class. & 3.25 & 0.973 \\
\hline 9 & I am afraid I will spend more money on my handphone bill because of mobile learning. & 3.56 & 1.115 \\
\hline 10 & I would like my lecturer to integrate mobile learning in my course. & 2.92 & 1.062 \\
\hline
\end{tabular}

TABLE IV.

DESCRIPTIVE STATISTICS OF RESPONDENTS’ TECHNOLOGY READINESS

\begin{tabular}{|c|c|c|c|}
\hline & $\begin{array}{c}\text { Items } \\
(\text { Overall mean }=3.299)\end{array}$ & Mean & $\begin{array}{l}\text { Standard } \\
\text { Deviation }\end{array}$ \\
\hline 1 & Technology gives people more control over their daily lives. & 3.65 & 0.939 \\
\hline 2 & Products and services that use the technologies are much more convenient to use. & 3.85 & 0.821 \\
\hline 3 & You like the idea of using mobile phone for the purpose of learning because you are not limited to regular working hours. & 3.31 & 1.008 \\
\hline 4 & You prefer to use the most advanced learning technology available. & 3.58 & 0.876 \\
\hline 5 & You like mobile phone programs that allow you to tailor things to fit your own needs. & 3.55 & 0.909 \\
\hline 6 & Society should not depend heavily on technology to solve its problems. & 3.67 & 1.024 \\
\hline 7 & You find that technology designed to make life easier usually has disappointing results. & 3.07 & 0.937 \\
\hline 8 & In general, you are among the first in your circle of friends to acquire new technology when it appears. & 2.67 & 1.058 \\
\hline 9 & You can usually figure out new high-tech products and services without help from others. & 3.13 & 0.996 \\
\hline 10 & You keep up with the latest technological developments in your areas of interest. & 3.42 & 0.977 \\
\hline 11 & You enjoy the challenge of figuring out high-tech gadgets. & 3.40 & 0.982 \\
\hline 12 & You are always open to learning about new and different technologies. & 3.76 & 0.917 \\
\hline
\end{tabular}

TABLE V.

CORRELATIONS BETWEEN MOBILE LEARNING READINESS,TECHNOLOGY READINESS, AND DEMOGRAPHIC FACTORS

\begin{tabular}{|c|c|c|c|c|c|c|c|c|c|}
\hline Components & $\begin{array}{l}\text { Mobile learning } \\
\text { readiness }\end{array}$ & $\begin{array}{l}\text { Technology } \\
\text { readiness }\end{array}$ & Gender & Age & Ethnic & Program & $\begin{array}{l}\text { Year of } \\
\text { Study }\end{array}$ & Institution & $\begin{array}{c}\text { Field of } \\
\text { Study }\end{array}$ \\
\hline Mobile learning readiness & 1 & & & & & & & & \\
\hline Technology readiness & $.436^{* *}$ & 1 & & & & & & & \\
\hline Gender & .012 & $-.141^{* *}$ & 1 & & & & & & \\
\hline Age & .031 & -.069 & $.091^{*}$ & 1 & & & & & \\
\hline Ethnic & .020 & .041 & -.079 & $.163^{* *}$ & 1 & & & & \\
\hline Program & -.022 & .072 & .023 & $-.560^{* *}$ & $-.121^{* *}$ & 1 & & & \\
\hline Year of Study & .060 & -.003 & .057 & $.382^{*}$ & .076 & $-.389^{* *}$ & 1 & & \\
\hline Institution & -.043 & .005 & $.151^{* *}$ & .022 & $-.094^{*}$ & -.079 & $.096^{*}$ & 1 & \\
\hline Field of Study & .025 & .024 & $-.084^{*}$ & .072 & .018 & $-.129^{* *}$ & -.004 & $-.104^{*}$ & 1 \\
\hline
\end{tabular}

${ }^{*}$ Correlation is significant at the 0.05 level (2-tailed).

${ }^{* *}$ Correlation is significant at the 0.01 level (2-tailed).

in this study that respondents' readiness for mobile learning has a significant positive relationship with their technology readiness. This suggests that respondents who are ready for technology in general would also be ready for the use of mobile learning as one of teaching-learning approach in their university. This is in accordance with another study which reported that respondents who have adequate knowledge and awareness to use a certain technology in their educational environment would also be ready to use mobile learning at their institution [64].Therefore, technological awareness seems to be an important first step in increasing students' readiness to embrace mobile learning.

In conclusion, despite demonstrating an interest towards mobile learning, students are still not quite ready and uncertain about what it offers to assist their learning process. In light of the study findings, much effort are still needed to ensure a successful implementation of mobile learning in Malaysian higher education, considering that students are still moderately ready and aware of its educational benefits. Bottom line is, what and how far does it takes for Malaysian university students to be fully ready 
for mobile learning implementation? Since the study was carried out through quantitative basis only, conclusion on Malaysian university students' readiness towards mobile learning cannot with any confidence be generalized. It would require further investigation, particularly through a more qualitative study nature by involving other stakeholders in Malaysian higher education. Yet, there are issues that were revealed in this study that could possibly need further research focus, such as by examining the implications and issues surrounding the development and implementation of mobile learning in higher learning institutions.

The implications of mobile learning on higher education are far reaching. Consequently, it will not be surprising that people around the world will begin to embrace mobile learning as a significant part of their educational process. Considering the trend, mobile learning could be a boom in Malaysian higher education within the next few years and this has called for all policy makers and stakeholders to be ready for it.

\section{ACKNOWLEDGMENT}

The authors would like to thank Universiti Sains Malaysia for the support of this study under the Research University Team (RUT) grant.

\section{REFERENCES}

[1] H. Dzakiria (2004), "Technology does not always teach distance learners, but effective distance teachers do," Malaysian Online Journal ofInstructionalTechnology, vol.1, no.1, 2004.

[2] D. Passey, C. Rogers, J. Machell, and G. McHugh, The motivational effect of ICT on pupils, (Nottingham, DfES), 2004, available at http://webarchive.nationalarchives.gov.uk/20130401151715/ http://www.education.gov.uk/publications/eOrderingDownload/Df ES-0794-2003.pdf

[3] G. Subramaniam, "Confronting Asian Concerns in Engaging Learners to Online Education," International Education Studies, vol. 1, no. 4, pp. 10-18, 2008. http://dx.doi.org/10.5539/ies. v1n4p10

[4] L. Chmiliar, "Mobile Learning - Student Perspectives." In J. Sanchez \& K. Zhang (Eds.), Proceedings of World Conference on E-Learning in Corporate, Government, Healthcare, and Higher Education, Chesapeake, VA: AACE, pp. 1646-1651, 2010.

[5] S. Mahamad, M.N. Ibrahim, M.I.A.M.Foad, and S.M. Taib, "Open source implementation of m-learning for primary schools in Malaysia", International Journal of Social Sciences, vol. 3, no. 4, pp. 309-313, 2008.

[6] T. Lim, M. Fadzil, and N. Mansor, "Mobile Learning via SMS at Open University Malaysia: Equitable, Effective, and Sustainable", International Review of Research in Open and Distance Learning, vol. 12, no. 2, pp. 122-137, 2011.

[7] Malaysian Communications and Multimedia Commission (MCMC), Facts \& Figures - Statistics \& Records, 2010, available at http://www.mcmc.gov.my.

[8] P.Y. Ng, K. Voges, and C.L. Goi, The importance of mobile phone applications to young consumers: an exploratory study in Malaysia, 2010, available at http://anzmac2010.org/proceedings/ pdf/anzmac10Final00103.pdf on June 5

[9] F. Al-Fahad, "Students' attitudes and perceptions towards the effectiveness of mobile learning in King Saud University, Saudi Arabia", The Turkish Online Journal of Educational Technology TOJET, vol. 8, no.2, 2009.

[10] M.I. Yousuf, "Effectiveness of mobile learning in distance education", Turkish Online -Journal of Distance Education, vol. 8, no. 4, pp. 113-124, 2007.

[11] F. Khaddage and Z. Wanlei, "A Mobile Learning model for Universities-Re-blending the current learning environment",International Journal of Interactive Mobile Technologies (iJIM), vol. 3, pp-18, 2009.

[12] J. R. Corbeil and M. E. Valdes-Corbeil, "Are You Ready for Mobile Learning?’Educause Quarterly, vol. 30, no.2, 2007.
[13] A. Trifonova, E. Georgieva, and M. Ronchetti,"Determining students' readiness for mobile learning", In Proceedings of the $5^{\text {th }}$ WSEAS International Conference on E-ACTIVITIES, Venice Italy, November 20-22, 2006.

[14] P.T.J. James, "Mobile-learning: Thai HE student perceptions and potential technological impacts", International Education Studies, vol. 4, no. 2, pp. 182-194, 2011. http://dx.doi.org/10.5539/ies. v4n 2 p 182

[15] J. Percival and N. Percival, "Engineering Students' Perceptions of Mobile Learning", In Proceedings of the World Congress on Engineering and Computer Science 2008 WCECS 2008, October 22 24, 2008 .

[16] J. Frand, "The Information-Age Mindset: Changes in Students and Implications for Higher Education", EDUCAUSE Review, vol. 35, no. 5, pp.14-18, 2000.

[17] E. A. Howard, "How do Millennial Engineering and Technology Students Experience Learning Through Traditional Teaching Methods Employed in the University Setting?", (Degree Theses. Department of Computer Graphics Technology)2011, available at http://docs.lib.purdue.edu/cgttheses/1

[18] B. Dimitrios, S. Labros, K. Nikolaos, K. Maria, K. Athanasios, "Traditional Teaching Methods Vs. Teaching Through The Application Of Information And Communication Technologies In The Accounting Field: Quo Vadis?", European Scientific Journal, vol. 9, No. 28, pp. 73-101, 2013

[19] M. Prensky, "Digital natives, digital immigrants", On the Horizon. MCB University Press, vol. 9, no. 5, 2001.

[20] U. Gasser, and J. G. Palfrey, "Born digital: Understanding the first generation of digital natives", New York: Basic Books, 2008

[21] S. Shaw, and D. "Fairhurst, Engaging a New Generation of Graduates", Education \& Training, vol. 50, no.5, pp. 366-378, 2008 http://dx.doi.org/10.1108/00400910810889057

[22] A. G. Lindsey, and A. S. William, "Millennials and Technology: Addressing the Communication Gap in Education and Practice 2014", Organization Development Journal, pp. 64-75, Winter 2014.

[23] C. Dede, "Enabling distributed-learning communities via emerging technologies", Proceedings of the 2004 Conference of the Society for Information Technology in Teacher Education (SITE) (Charlottesville, Va.: American Association for Computers in Education, 2004), pp. 3-12, 2004.

[24] C. Price, "Why don't my students think I'm groovy? The new "Rs" for engaging Millennial learners", The Teaching Professor, vol 1, pp.1-6, 2009 available at http://www.drtomlifvendahl. com/Millennial\%20Characturistics.pdf

[25] M. Wilson, and L.E. Gerber, "How generational theory can improve teaching: strategies for working with millennials", Currents in Teaching and Learning, vol.1, no. 1, pp. 29-44, 2008.

[26] A.Yuen, N. Law, and K. Wong, "ICT implementation and school leadership Case studies of ICT integration in teaching and learning”, Journal of Educational Administration, vol. 41 no. 2, pp. 158-170, 2003. http://dx.doi.org/10.1108/09578230310464666

[27] A. Hassan, "Difference in Male and Female about the Awareness of Educational Technology at B. Ed Level", Pakistan Journal of Life and Social Sciences, vol. 8, no. 2, pp. 89-93, 2010.

[28] M. O. M. El-Hussein, and J. C. Cronje, "Defining Mobile Learning in the Higher Education Landscape", Educational Technology \& Society, vol. 13, no. 3, pp. 12-21, 2010.

[29] Nielsen Survey, "The Mobile Consumer: A Global Snapshot", 2013 available at http://www.nielsen.com/content/dam/corporate/ uk/en/documents/Mobile-Consumer-Report-2013.pdf

[30] Statista, "Forecast: multiple mobile device ownership worldwide from 2011 to 2016", 2012, available at http://www.statista.com/ statistics/245501/multiple-mobile-device-ownership-worldwide/

[31] Y. Park, "A Pedagogical Framework for Mobile Learning: Categorizing Educational Applications of Mobile Technologies into Four Types International Review of Research in Open and Distance Learning”, vol. 12, no. 2, pp pp. 79-102, February 2011.

[32] Z.W. Abas, L.P. Chng, and N. Mansor, "A Study On Learner Readiness For Mobile Learning At Open University Malaysia”, In IADIS International Conference Mobile Learning 2009, Barcelona, Spain, February 26-28, 2009.

[33] M. Shuib, A. Abdullah, S.N. Azizan, and T. Gunasegaran, "Designing an Intelligent Mobile Learning Tool for Grammar Learning (i-MoL)", International Journal of Interactive Mobile Technologies, vol. 9, no. 1, pp. 41-46, 2015. http://dx.doi.org/10.3991/ ijim.v9i1.4238 
[34] J. Rikala, "Mobile Learning - a Review of Current Research", Reports of the Department of Mathematical Information Technology Series E. Educational Technology, no. E 2/2013, pp. 1-65, 2013.

[35] I. Ismail, S. F. Bokhare, S. N. Azizan, and N. Azman, "Teaching via mobile phone: A case study on Malaysian teachers' technology acceptance and readiness", Journal of Educators Online, vol. 10, no. 1, pp.1-38, 2013

[36] A. Kukulska-Hulme, and J. Traxler, "Mobile learning: A handbook for educators and trainers", London: Routledge, 2005.

[37] C. Quinn, "mLearning: Mobile, Wireless, in your Pocket Learning", LineZine, Fall 2000 available at http:// www.linezine.com/2.1/features/cqmmwiyp.htm.

[38] T. Goh, and D. Kinshuk, "Structural Equation Modelling Approach in Multiplatform e-learning system evaluation", In S. Spencer and A. Jenkins (Eds), Proceedings of the 17th Australian Conference on Information Systems (ACIS) 2006, Australasian Association for Information Systems, 2006.

[39] T. Yamaguchi, "Vocabulary learning with a mobile phone", Program of the 10th Anniversary Conference of PanPacific Association of Applied Linguistics, Edinburgh, UK, 2005.

[40] S.J. Geddes, "Mobile learning in the 21st century: Benefit for learners", Knowledge Tree e-journal: An E-journal of Flexible Learning in VET, vol. 30, no. 3, pp. 214-218, 2004.

[41] MoLeNET, Mobile learning myths, 2010, available at http://web.archive.org/web/20101015234706/http://www.molenet. org.uk/mobilearinprac/myths

[42] N. Winters, "What is mobile learning?", In M. Sharples (Ed.), Big issues in mobile learning: Report of a workshop by the kaleidoscope network of excellence mobile learning initiative, University of Nottingham, 2006.

[43] K. Peters, "m-Learning: Positioning educators for a mobile, connected future", International Journal Of Research in Open and Distance Learning, vol. 8, no. 2, pp. 1-17, 2007.

[44] T.H. Brown, "Towards a model for m-learning in Africa", International Journal of ELearning, vol. 4, no. 3, pp. 299-315, 2005.

[45] R. Pea, and H. Maldonado, "WILD for learning: Interacting through new computing devices anytime, anywhere", In R. K. Sawyer (Ed.), The Cambridge handbook of the learning sciences, Cambridge: Cambridge University Press, pp. 427-441, 2006.

[46] J. Traxler, "Will student devices deliver innocation, inclusion, and transformation?", Journal of the Research Center for Educational Technology, vol. 31, no. 2, pp. 129-138, 2010.

[47] L. Naismith, P. Lonsdale, G. Vavoula, and M. Sharples, "Literature Review in Mobile Technologies and Learning", Bristol: NESTA FutureLab, 2004.

[48] J. Traxler, "Defining mobile learning", In IADIS International Conference Mobile Learning, 2005.

[49] C. O'Malley, G. Vavoula, J. Glew, J. Taylor, M. Sharples, and P. Lefrere, "Guidelines for learning/teaching/tutoring in a mobile environment", MOBIlearn - Pedagogical Methodologies and Paradigms, vol. 4, 2005.

[50] D. Laurillard, "Pedagogical forms of mobile learning: Framing research questions", In N. Pachler(Ed.), Mobile learning: Towards a research agenda (Vol. 1, pp. 33-54). London: WLE Centre, Institute of Education, 2007.

[51] J.H. Valk, A. T. Rashid, and L. Elder, "Using Mobile Phones to Improve Educational Outcomes: An Analysis of Evidence from Asia", The International Review of Research in Open and Distance Learning, vol.11, no.1, pp.117-140, 2010.

[52] A. Valenta, D. Therriault, M. Dieter, and R. Mrtek, "Identifying Student Attitudes and Learning Styles in Distance Education", Journal of asynchronous learning networks, vol. 5, no. 2, pp. 111127, 2001.

[53] M. J. W. Lee, and A. Chan, "Reducing the Effects of Isolation and Promoting Inclusivity for Distance Learners through Podcasting", Turkish Online Journal of Distance Education, TOJDE, vol. 8, no. 1 , pp. $85-105,2007$.

[54] M. McMahon, and R. Pospisil, "Laptops for a digital lifestyle: The role of ubiquitous mobile technology in supporting the needs of millennial students", Paper presented at EDUCAUSE Australasia 2005: The next wave of collaboration, Auckland, 2005.

[55] D. Oblinger, "Boomers, Gen-Xers, and Millennials: Understanding the New Students", EDUCAUSE Review, vol. 38, no. 4, pp. 36-40,42,44-45, 2003 .
[56] R. S. Cobcroft, S. Towers, and J. Smith, " Mobile learning in review: Opportunities and challenges for learners, teachers, and institutions", Proceedings of the Online Learning and Teaching Conference 2006, pp. 21-30, 2006.

[57] Malaysian Communications and Multimedia Commission (MCMC), Report on handphone users survey 2008, 2008, available at http://www.skmm.gov.my/link file/facts figures/stats/pdf/ Handphone Users Survey 2008.pdf

[58] P. Honey, A. Mumford, The Learning Styles Helper's Guide, Maidenhead, UK: Peter Honey, 2000.

[59] D.A. Kolb, "Learning Styles and Disciplinary Differences", The Modern American College, pp. 232-255, 1981.

[60] N.D. Fleming, and C. Mills, "Not Another Inventory, Rather a Catalyst for Reflection", To Improve The Academy, vol. 11, pp. 137-155, 1992.

[61] P. Pollara, and K.K. Broussard, "Student Perceptions of Mobile Learning: A Review of Current Research", In Proceedings of Society for Information Technology \& Teacher Education International Conference 2011 (pp. 1643-1650). Chesapeake, VA: AACE, 2011.

[62] S. Hussin, M. R. Manap, Z. Amir, and P. Krish. "Mobile learning readiness among Malaysian students at higher learning institutes", Asian Social Science, vol. 8, no. 12, pp. 276-283., 2012. http://dx.doi.org/10.5539/ass.v8n12p276

[63] E.D. Wagner, "Enabling Mobile Learning", EDUCAUSE Review, vol. 40, no. 3, pp. 40-53, 2005.

[64] N.S. Alzaza, Opportunities for utilizing mobile learning services in the Palestinian Higher Education, 2012, available at http://www.iajet.org/iajet_files/vol.2/no.4/Opportunities $\% 20$ for $\% 2$ 0Utilizing $\% 20$ Mobile $\% 20$ Learning $\% 20$ Services $\% 20$ in $\% 20$ the $\% 2$ 0Palestinian\%20Higher\%20Education.pdf

[65] A. Parasuraman, "Technology Readiness Index (TRI) a multipleitem scale to measure readiness to embrace new technologies",Journal of Service Research, vol. 2, no. 4,pp. 307-320, 2000. http://dx.doi.org/10.1177/109467050024001

[66] R.A. Peterson, “A Meta-analysis of Cronbach's Coefficient Alpha”, Journal of Consumer Research, vol. 21, pp. 381-391, 1994. http://dx.doi.org/10.1086/209405

[67] M. A. Embi and N. M. Nordin, Mobile learning: Malaysian initiatives and research findings, 2013, Available at http://www.mohe.gov.my/portal/images/penerbitan/JPT/Pengurusa n Pembangunan Akademik/Mobile Learning Malaysian Initiat ives and Research Findings.pdf

[68] M. Mohamad, J. Woollard, "Bringing change in secondary schools: can mobile learning via mobile phones be implemented in Malaysia?" Paper presented at the 4th International Malaysian Educational Technology Convention, Kuala Lumpur, Malaysia, 2010.

[69] N.F. Sa'don, H. M. Dahlan, and A. Ibrahim. "Usage of mobile Learning in Malaysian secondary education: Stakeholders' view", Journal of Information Systems Research and Innovation, vol.6, pp.42-50, 2014.

[70] J. Mahat, A. F. M. Ayub, and S. Luan, "An assessment of students' mobile self-efficacy, readiness and personal innovativeness towards mobile learning in higher education in Malaysia",Procedia-Social and Behavioral Sciences, vol. 64, pp. 284290, 2012. http://dx.doi.org/10.1016/j.sbspro.2012.11.033

[71] N. Cavus, H. Bicen, and U. Akcil, "The opinions of information technology students on using mobile learning", Paper presented at the 08 International Conferences on Educational Sciences,Eastern Mediterranean University, Magosa, North Cyprus,23-25 June, 2008.

\section{AUTHORS}

Issham Ismail is with School of Distance Education, Universiti Sains Malaysia, Penang, Malaysia

Siti Norbaya Azizan is with School of Distance Education, Universiti Sains Malaysia, Penang, Malaysia (sitinorbaya49@gmail.com)

Thenmolli Gunasegaran is with School of Educational Studies, Universiti Sains Malaysia, Penang, Malaysia

Submitted 30 November 2015. Published as resubmitted by the authors 23 March 2016. 